УдК 001.891.3:657.441

DOI: $10.15673 /$ fie.v12i3.1812

\author{
Євтушевська 0.0 . \\ кандидат економічних наук, доцент \\ кафедра обліку та аудиту \\ E-mail: olga163alex@gmail.com \\ ORCID ID: 0000-0003-4869-5123 \\ Чернов К.І. \\ магістрант \\ кафедра обліку та аудиту \\ Одеська національна академія харчових технологій \\ вул. Канатна 112, м. Одеса, Україна, 65039 \\ E-mail: konstantin.khilko@gmail.com \\ ORCID ID: 0000-0002-0814-0011
}

\title{
ТЕОРЕТИЧНІ АСПЕКТИ ВЛАСНОГО КАПІТАЛУ ПІДПРИЄМСТВА: СУТНІСТЬ ТА СТРУКТУРА
}

\begin{abstract}
У статті досліджено дефініції поняття «власний капітал» із точки зору різних науковців. Проаналізовано найбільш розповсюджені трактування поняття «власний капітал» та визначено найбільш точні з них на погляд авторів. Розкрито сутність, формування, функціонування та відтворення підприємницького капіталу. Досліджено складові власного капіталу та можливості оцінки впливу фрінансової структури капіталу на рентабельність підприємства. Запропоновано згруповану структуру власного капіталу. Розкрито значення облікової інформації про власний капітал підприємства для внутрішніх і зовнішніх користувачів. Розглянуто джерела формування власного капіталу на підприємстві. Розкрито особливості формування окремих складових власного капіталу. Досліджено природу власного капіталу через функції, які він виконує на підприємстві. Узагальнено теоретичні засади формування власних фінансових ресурсів підприємства, що забезпечують його майбутній розвиток. Виявлено проблеми формування власного капіталу на підприємстві та надано пропозиції щодо їх удосконалення.

Ключові слова: капітал, власний капітал, активи, зобов'язання, поняття власного капіталу, структура власного капіталу.
\end{abstract}

This work is licensed under a Creative Commons Attribution 4.0 International License http://creativecommons.org/licenses/by/4.0/

Постановка проблеми та її зв'язок з важливими науковими та практичними завданнями. Під поняттям «капітал» найчастіше мається на увазі поняття «власність». Коли створюється підприємство, стартовий капітал втілюється саме в активах, які інвестують засновники (учасники), і є вартістю майна, що належить підприємству.

Складовими майна підприємства є матеріальні, нематеріальні та фінансові ресурси, які $є$ носіями прав власності окремих суб'єктів.

Актуальність теми зумовлена тим, що власний капітал має визначальне місце у створенні та функціонуванні підприємства й користується статусом «гаранту» організації підприємництва.

Власний капітал - це основа й фундамент стабільного розвитку підприємства. В міжнародних стандартах бухгалтерського обліку зазначено наступне визначення власного капіталу: «Власний капітал - це залишкова частка в активах підприємства після вирахування всіх його зобов'язань». Іншими словами, власний капітал можна трактувати як чистий капітал або чисті активи суб'єкта господарської діяльності і $є$ основним джерелом фінансування. Розмір власного капіталу - це свого роду індикатор для інвесторів, які обирають підприємство для здійснення своїх капіталовкладень.

Аналіз останніх публікацій 3 проблеми. Перші теоретичні розробки, які були визначальними у подальшому розвитку обліку власного капіталу, належать Ж. Саварі, Л. Пачолі, Б. Котрульї. Також серед іноземних учених, які змогли посприяти удосконаленню обліку власного капіталу у різні часові періоди, слід виділити Ж. Ришар, В. Рігер, М.Ю. Медведєв, Ф. Ляйтнер, Н.А. Литньова, Ж.Б. Дюмарше, П. Герстнер, А.В. Бугайова, Ф. Беста, Л. Батардон, В.Е. Ануфрієв, Н. де Анастасіо, Ж. Андре.

Питанням формування складових власного капіталу та трактування їх сутності з метою організації обліку в сучасних умовах займалися й вітчизняні науковці, а саме: В.В. Сопко, Н.М. Ткаченко, С.В. Пушкар, I.P. Поліщук, О.І. Пилипенко, М.М. Мосійчук, Г.Г. Кірейцев, С.Ф. Голов, М.В. Власова, Ф.Ф. Бутинець, С.М. Бичкова, П.С. Безруких, А.С. Бакаєв та інші.

Формулювання цілей дослідження. Метою даної статті $є$ узагальнення теоретичних засад ви- 
знання та трактування власного капіталу підприємства як економічної категорії.

Виклад основних результатів та їх обгрунтування. Сутність капіталу, його роль у здійсненні підприємницької діяльності завжди були предметом обговорення, дискусії як в економічній теорії, так і 3 позиції ведення бухгалтерського фінансового обліку. Капітал трактують як самозростаючу вартість, як вартість, що приносить додану вартість. Найчастіше під капіталом розуміються джерела життєдіяльності підприємства, за допомогою яких функціонує і розвивається підприємство.

У таблиці 1 наведено трактування капіталу в трьох аспектах.

3 господарського (економічного) погляду капітал об'єднує майно, власність підприємства, що включає конкретні, придатні для здійснення діяльності блага, активи, здатні в майбутньому давати економічні вигоди. Економічний підхід до визначення величини капіталу передбачає необхідність контролю за процесом формування такого капіталу, оскільки 3 точки зору управління фінансовими ресурсами важливим $€$ не стільки потенційна величина внесеного засновниками капіталу, а й реальне його поповнення за рахунок внутрішніх та зовнішніх джерел в процесі діяльності підприємства.

3 юридичного погляду, капітал - це абстрактне право розпоряджатися майном підприємства, власність, що належить засновникам підприємства після погашення зобов'язань. 3 юридичної точки зору капітал характеризує, з одного боку, величину умовно відокремленого майна, право власності на яке перейшло до підприємства, як юридичної особи; з іншого боку - це зобов'язання щодо коштів, які належать засновникам (учасникам).

3 позиції бухгалтерського обліку капітал становить суму ресурсів, інвестованих у бізнес, у діяльність підприємства. Такими ресурсами формування майна підприємства $\epsilon$ власні та залучені зі сторони джерела, що прирівнюються до власного і залученого капіталу. 3 бухгалтерської (балансової) точки зору капітал власників визначається як залишкова частка прав на активи підприємства, оскільки зобов'язання перед кредиторами мають виконуватися у першу чергу.

Таблиця 1

Трактування капіталу в трьох позиціях*

\begin{tabular}{|c|c|c|}
\hline \multicolumn{2}{|c|}{ КАПІТАЛ } \\
\hline Економічна позиція & Юридична позиція & Облікова позиція \\
\hline $\begin{array}{c}\text { Вартість, яка створює додаткову } \\
\text { вартість }\end{array}$ & $\begin{array}{c}\text { Атрибут, який символізує } \\
\text { відносини власності }\end{array}$ & $\begin{array}{c}\text { Джерело для формування активів } \\
\text { підприємства }\end{array}$ \\
\hline
\end{tabular}

*складено авторами з використанням джерел $[2,4]$

У вітчизняній літературі існує безліч різних точок зору стосовно визначення поняття «власний капітал». Основні підходи щодо трактування даної економічної категорії висвітлено в табл. 2 .

Таблиця 2

Визначення поняття «власний капітал»*

\begin{tabular}{|c|l|}
\hline Автор & \multicolumn{1}{c}{ Визначення } \\
\hline Ф.Ф. Бутинець & $\begin{array}{l}\text { Власний капітал - це загальна вартість засобів підприємства, які належать йому на пра- } \\
\text { вах власності і використовуються ним для формування його активів }\end{array}$ \\
\hline О.Й. Вівчар & $\begin{array}{l}\text { Фінансові ресурси, які вкладає підприємство для організації та фінансування господар- } \\
\text { ської діяльності }\end{array}$ \\
\hline А.А. Горбатенко & $\begin{array}{l}\text { Власний капітал виражає загальну величину коштів у грошовій, матеріальній і немате- } \\
\text { ріальній формах, вкладених в активи підприємства }\end{array}$ \\
\hline Я.П. Іщенко & $\begin{array}{l}\text { Власний капітал - необхідний фактор виробництва, він включає компоненти боргу, не- } \\
\text { розподілений прибуток, привілейовані акції і звичайні акції }\end{array}$ \\
\hline Л.І. Катан & $\begin{array}{l}\text { Власний капітал - це певне вираження фінансових відносин, що виникають між акціо- } \\
\text { нерним товариством (корпорацією) та іншими суб'єктами господарювання з приводу } \\
\text { його формування та використання. }\end{array}$ \\
\hline В. Королюк & $\begin{array}{l}\text { Власний капітал - це сукупність економічних благ у грошовій, матеріальній і нематері- } \\
\text { альній формах, які залучаються до економічного процесу діяльності суб'єкта господа- } \\
\text { рювання без визначення терміну повернення їх власникам і здатні генерувати доходи }\end{array}$ \\
\hline О.А. Нужна & $\begin{array}{l}\text { Власний капітал - це загальна вартість власних засобів підприємства, які належать йо- } \\
\text { му на правах власності і використовуються ним для формування його активів }\end{array}$ \\
\hline В.В. Сопко & $\begin{array}{l}\text { Власний капітал - це сума належних підприємству власних коштів, отриманих в ре- } \\
\text { зультаті його діяльності чи від засновників (учасників) у вигляді внесків, акцій, паїв } \\
\text { тощо, або безоплатно залишених на підприємстві }\end{array}$ \\
\hline *складено авторами з використанням джерел [4,6,7,10,11,13,14]
\end{tabular}


Аналізуючи наведені в таблиці визначення, можна помітити, що автори пояснюють економічний сенс власного капіталу, спираючись на його ключову функцію - забезпечити підприємство власними ресурсами, необхідними для початку і продовження господарської діяльності.

Отже, ми вважаємо, що трактування поняття власного капіталу такими авторами, як О.Й. Вівчар, Я.П. Іщенко та Л.І. Катан є недосить повні, тому що:

- внески до власного капіталу можуть бути здійснені не лише у формі грошових коштів;

- до складу власного капіталу входять не лише прибутки, борги та акції;

- фінансові відносини 3 приводу власного капіталу виникають не лише за участі акціонерного товариства.

Щодо трактування поняття власного капіталу останніми авторами, то вони, на нашу думку, є досить змістовними. Зокрема можна виділити трактування цього поняття такими авторами, як А.А. Горбатенко та Т.М. Королюк, оскільки в даних тлумаченнях охоплюються усі можливі форми внесків до власного капіталу.

Власний капітал становить:

- ресурси підприємства, акумульовані його власниками у вигляді внесків до зареєстрованого статутного та іншого капіталу, а також набутого за час господарської діяльності майна;

- загальну вартість належних підприємству коштів на правах власності, які воно використовує 3 метою формування своїх активів;

- належні підприємству джерела, які вкладені засновниками (учасниками) або залишені ними на підприємстві з оподатковуваного прибутку без визначення строку повернення.

Майно, активи формуються за рахунок власного капіталу, інвестованого в них, і характеризуються як чисті активи підприємства, хоча цю категорію слід сприймати як певну умовність 3 кількох причин:

- на практиці дуже важко розділити, які активи придбані за власні кошти підприємства (що $є$ чистими активами), а які за рахунок залучених джерел (що не відносяться до таких);

- пріоритетність у поверненні капіталу завжди мають зобов'язання, власні джерела (що символізують чисті активи) повертаються за залишковим принципом;

- чисті активи не можуть відображати поточну ринкову вартість майна підприємства, оскільки є лише різницею між бухгалтерською оцінкою активів i кредиторською заборгованістю.

Залучений капітал - це ресурси, що надійшли зі сторони і тимчасово використовуються в обороті підприсмства. Такі ресурси характеризують капітал підприємства у формі зобов'язань.

Встановлюючи межу між капіталом власників і зобов'язаннями у формі кредиторської заборгованості, треба пам'ятати, що:
- власний капітал - це головний ризиковий капітал, власність суб'єкта господарювання;

- власний капітал не дає гарантованого прибутку для власників;

- щодо нього не встановлено чіткого графіку повернення засновникам, інвесторам;

- до власного капіталу не можуть бути пред'явлені обов'язкові вимоги з виплати дивідендів;

- власний капітал може поповнюватися за рахунок результатів діяльності підприємства, у формі реінвестиції прибутку, переоцінки активів та інших джерел;

- власний капітал може виступати джерелом для здійснення ризикових інвестицій в інші суб'єкти. До того ж часткова чи повна втрата інвестованого капіталу не призводить до юридичної відповідальності перед власниками.

Натомість, зобов'язання 3 повернення залученого капіталу обов'язково повинні бути виконані, вони мають точну оцінку, строки погашення. Суб'єкти, до яких виникли боргові зобов'язання, повинні бути ідентифіковані в аналітичному обліку як окремі юридичні, фізичні особи, або групи осіб.

У момент створення підприємства його стартовий капітал представляють активи, інвестовані засновниками (учасниками) у майно підприємства як внески до зареєстрованого статутного та іншого капіталу.

В процесі здійснення підприємницької діяльності підприємство також може користуватися й залученими коштами, через що виникають зобов'язання.

Відому балансову формулу (Активи = Пасиви) можна трансформувати так [2]:

Активи = Власний капітал + Зобов'язання

Пріоритетність зобов'язань порівняно 3 власним капіталом можна подати формулою [2]:

Власний капітал $=$ Активи - Зобов'язання

Це означає, що за необхідності власний капітал повертається засновникам за залишковим принципом, після погашення зобов'язань підприємства.

Зобов'язання за боргами підтверджують вимоги й права кредиторів на активи підприємства і $\epsilon$ більш пріоритетними порівняно з вимогами власників. Тому згідно НП(С)БО 1 «Загальні вимоги до фінансової звітності» власний капітал - це частина в активах підприємства, що залишається після вирахування його зобов'язань.

Для більш детального трактування власного капіталу необхідно визначити його складові. Детальний склад та зміст власного капіталу наведено в табл. 3. 
Складові власного капіталу та їх зміст*

\begin{tabular}{|c|c|}
\hline $\begin{array}{l}\text { Стаття власного } \\
\text { капіталу }\end{array}$ & Зміст \\
\hline $\begin{array}{l}\text { Зареєстрований } \\
\text { (пайовий) капітал }\end{array}$ & $\begin{array}{l}\text { - зареєстрована вартість акцій для підприємств, створених у формі акціонерних } \\
\text { товариств, або сума оголошеного статутного капіталу для підприємств інших } \\
\text { організаційно-правових форм господарювання, яка зафіксована у статутних } \\
\text { документах; } \\
\text { - сума пайових внесків фізичних та юридичних осіб, якщо це передбачається в } \\
\text { статутних документах; } \\
\text { - інший зареєстрований капітал; } \\
\text { - внески до незареєстрованого капіталу. }\end{array}$ \\
\hline Капітал у дооцінках & сума дооцінки (уцінки) необоротних активів та фінансових інструментів \\
\hline Додатковий капітал & $\begin{array}{l}\text { - сума, на яку вартість продажу акцій перевищує їх номінальну вартість (емі- } \\
\text { сійний дохід); } \\
\text { - додаткові внески засновників без прийняття рішення про зміни розміру ста- } \\
\text { тутного капіталу; } \\
\text { - накопичені курсові різниці; } \\
\text { - вартість активів, які отримані підприємством від фізичних чи юридичних осіб } \\
\text { безоплатно; } \\
\text { - інші види додаткового капіталу. }\end{array}$ \\
\hline Резервний капітал & $\begin{array}{l}\text { сума резервів, що створені підприємством згідно з чинним законодавством чи } \\
\text { статутними документами за рахунок нерозподіленого прибутку }\end{array}$ \\
\hline $\begin{array}{l}\text { Нерозподілений при- } \\
\text { буток (непокритий зби- } \\
\text { ток) }\end{array}$ & $\begin{array}{l}\text { - сума нерозподіленого прибутку поточного і минулих років, а також викорис- } \\
\text { таного у звітному році прибутку; } \\
\text { - сума непокритих збитків поточного і минулих років }\end{array}$ \\
\hline $\begin{array}{l}\text { Неоплачений } \\
\text { капітал }\end{array}$ & заборгованість засновників (учасників) щодо внесків до статутного капіталу \\
\hline
\end{tabular}

Дані складові відображають суму, яку засновники дали в розпорядження підприємства у формі внесків або залишили як нерозподілений прибуток. Усі складові капіталу можна умовно розділити на групи, які наведено в табл. 4.

Таблиця 4

Складові власного капіталу за окремими групами*

\begin{tabular}{|c|l|c|}
\hline Вкладений капітал & \multicolumn{1}{|c|}{ Накопичений капітал } & $\begin{array}{c}\text { Регулюючий } \\
\text { капітал }\end{array}$ \\
\hline \multirow{2}{*}{$\begin{array}{c}\text { Зареєстрований } \\
\text { (пайовий) капітал }\end{array}$} & $\begin{array}{l}\text { Капітал у дооцінках } \\
\text { Додатковий капітал (за вирахуванням іншого вкладеного } \\
\text { капіталу) }\end{array}$ & $\begin{array}{c}\text { Вилучений } \\
\text { капітал }\end{array}$ \\
\cline { 1 - 2 } Інший вкладений капітал & Резервний капітал & $\begin{array}{c}\text { Неоплачений } \\
\text { капітал }\end{array}$ \\
\cline { 2 - 3 } & Нерозподілені прибутки (непокриті збитки) \\
\hline
\end{tabular}

*складено авторами з використанням джерел [2,4]

Спираючись на те, що сутність будь-якої категорії проявляється через виконувані нею функції, доцільно було б розглянути функції, які покладені на власний капітал.

Найбільш поширена функція - відповідальності і захисту прав кредиторів, тому що власний капітал, який відображено в балансі підприємства, є мірилом відносин відповідальності на підприємстві для зовнішніх користувачів, а також захистом для кредиторів від втрати їх капіталу.

Отже, власний капітал - це гарантія захисту прав кредиторів та критерій відповідальності. Тому гарантійна функція визначається іншими авторами як інша назва функції відповідальності й захисту прав кредиторів.

Окрім гарантії для зовнішніх користувачів, власний капітал також виконує функцію захисту, показуючи значення власного капіталу для власників. Чим більший розмір власного капіталу, тим краще підприємство захищене від впливу загрозливих для його існування факторів, бо збитки підприємства можуть покриватися саме за рахунок власного капіталу.

Функція довгострокового фінансування також $є$ важливою, оскільки внески у власний капітал можуть бути спрямовані на фінансування інвестиційної та операційної діяльності підприємства, а також на погашення заборгованостей протягом тривалого періоду часу. 
Окрім цього, власний капітал $є$ основою для нарахування дивідендів та розподілу майна, а це важливо для захисту корпоративних прав засновників та ефективного розподілу до фондів підприємства. 3 цією функцією пов'язана функція компенсації понесених збитків, бо саме за рахунок власного капіталу мають погашатися тимчасові збитки.

Регулятивна функція реалізується у випадку виходу засновника з товариства або під час ліквідації підприємства, коли визначається частка кожного 3 засновників при розподілі прибутку та збитку, а також у майні підприємства.

Під функцією довготермінового кредитування мається на увазі те, що власний капітал перебуває в розпорядженні підприємства необмежений час. Попри те, що дана функція з функцією довгострокового фінансування $є$ аналогічними, використання останнього формулювання є більш доцільним, враховуючи обмеженість кредитування.

Функція заснування та введення в дію підприємства (основоположна функція) проявляється в тому, що власний капітал у частині статутного - це фінансова база для початку діяльності нового суб'єкта господарської діяльності.

Функція самостійності та влади полягає в тому, що величина власного капіталу визначає те, наскільки незалежним є підприємства та який вплив на це підприємство мають його власники.

Частка власного капіталу в активах - це показник платоспроможності підприємства. Це вказує на ще одну важливу функцію - функцію кредитоспроможності. У разі надання кредиту перевагу нададуть тим підприємствам, які мають меншу кредиторську заборгованість та більший власний капітал.

Окрім цього, власний капітал фінансує проекти, які є ризиковими та під які проблематично залу- чити сторонні кошти. Це відображається функцією фінансування ризику.

Функція компенсації понесених збитків означає, що тимчасові збитки мають погашатись за рахунок власного капіталу.

Висновки та перспективи подальших досліджень. Капітал - одна з базових економічних категорій, сутність якої досліджується наукою вже багато століть. Власний капітал - це фундамент для початку та здійснення господарської діяльності підприємства. Це важливий показник, який відображає фінансовий стан підприємства. Мати та ефективно витрачати кошти власного капіталу, які сформовано за рахунок власних фінансових ресурсів, є запорукою прибутковості будь-якого суб'єкта господарювання, тому величина власного капіталу $є$ індикатором для зовнішніх користувачів інформації стосовно захищеності прав кредиторів, а також мірою відповідальності у відносинах господарювання.

Якщо говорити про шляхи збільшення власного капіталу, то можна виділити наступні:

- здійснення додаткових внесків власниками (учасниками, акціонерами);

- підвищення номінальної вартості акцій;

- спрямування до статутного капіталу додаткового капіталу у частині емісійного доходу;

- спрямування до статутного капіталу прибутку.

Крім того, для збільшення власного капіталу підприємство може розмістити прибуток в банку на депозиті до запитання, здавати своє майно в оренду, приймати безоплатну фінансову допомогу (якщо така буде запропонована), а також приділити більше уваги рекламі, щоб залучити більше клієнтів і, як наслідок, отримувати більший прибуток, що сприятиме збільшенню власного капіталу.

\section{Література}

1. Господарський кодекс України № 436-IV від 16.01.2003 р.: за станом на 16.08.2020 р. / Верховна Рада України. URL: https://zakon.rada.gov.ua/laws/show/436-15\#Text (дата звернення: 20.06.2020 p.)

2. Загальні вимоги до фінансової звітності: Національне положення (стандарт) бухгалтерського обліку №1: затв. наказом Мінфіну від 07.02.2013 p. № 73 за станом на 31.05.2019 p. URL: https: //zakon.rada.gov.ua/laws/show/z0336-13/page\#Text (дата звернення: 07.07.2020). 2004. $656 \mathrm{c}$.

3. Бланк І.А. Фінансовий менеджмент: навчальний курс. 2-е вид, перероб. і доп. К.: Эльга, Ника-Центр,

4. Бутинець Ф. Ф. Бухгалтерський фінансовий облік: підручник для студентів спеціальності «Облік і аудит» вищих навчальних закладів. 8-ме вид., доп. і перероб. Житомир: ПП «Рута», 2009. 912 с.

5. Варичева Р.В. Власний капітал: функціональний підхід до трактування сутності, напрями класифікації у вітчизняній та зарубіжній практиці // Вісник ЖДТУ. 2011. № 2 (52). С. 37-42.

6. Вівчар О., Саварин В. Власний капітал як фінансове джерело функціонування підприємства // Науковий вісник НЛТУ України. 2009. Вип. 19.5. С. 146-150.

7. Горбатенко А.А. Особливості формування власних фінансових ресурсів підприємств в Україні // Економічний вісник Переяслав-Хмельницького ДПУ імені Григорія Сковороди. 2010. Вип. 15/1. С. $195-201$.

8. Економічна теорія: політекономія: підручник / за ред. В. Д. Базилевича. 7-ме вид. К.: Знання-Прес., 2008. $719 \mathrm{c}$.

9. Загородній А. Г. , Партин Г. О. Бухгалтерський облік: основи теорії та практики: навч. посіб. 2-ге вид., перероб. і доп. К: Т-во «Знання», 2003. 327 с.

10. Іщенко Я.П., Галайда Л.В. Теоретичні основи формування власного капіталу підприємства // Науковий вісник Херсонського державного університету. 2015. Вип. 15. Ч. 1. С. 146-148. 
11. Катан Л.І. Фінансові ресурси підприємства та особливості їх формування // Вісник Дніпропетровського державного аграрно-економічного університету. 2014. № 6. С. 38-44.

12. Кірейцев Г. Г. Фінансовий менеджмент: навч.посібник / за ред. проф. Г. Г. Кірейцева. 3 вид., перероб. і доп. К.: ЦНЛ, 2004. 531 с.

13. Нужна О. Власний капітал сільськогосподарських підприємств: трактування, класифікація, структура // Збірник наукових праць Луцького національного технічного університету. Економічні науки. Сер. Облік і фінанси»-2012. Вип. 9(33). -Ч. 2. С. 498-507.

14. Сопко В.В. Власний капітал акціонерних товариств: особливості визначення та обліку // Науковий вісник Національного лісотехнічного університету України. 2007. Вип. 17.6. С. 246-253.

15. Терещенко О. О. Фінансова діяльність суб'єктів господарювання: навч. посібник. КНЕУ, 2003. 554 с.

16. Ткаченко Н. М. Бухгалтерський фінансовий облік, оподаткування і звітність: підручник. 3-те вид. допов. і перероб. К.: Алерта, 2008. 926 с.

Стаття надійшла 15.07.2020

Стаття прийнята до друку 29.07.2020

Доступно в мережі Internet 15.10.2020

Евтушевская О.А.

кандидат экономических наук, доцент

кафедра учета и аудита

E-mail: olga163alex@gmail.com

ORCID ID: 0000-0003-4869-5123

Чернов К.И.

магистрант

кафредра учета и аудита

Одесская национальная академия пищевых технологий

ул. Канатная, 112, г. Одеса, Украина, 65039

E-mail: konstantin.khilko@gmail.com

ORCID ID: 0000-0002-0814-0011

\section{ТЕОРЕТИЧЕСКИЕ АСПЕКТЫ СОБСТВЕННОГО КАПИТАЛА ПРЕДПРИЯТИЯ: СУЩНОСТЬ И СТРУКТУРА}

В статье исследованы дефиниции понятия «собственный капитал» с точки зрения различных ученых. Проанализированы наиболее распространенные трактовки понятия «собственный капитал» и определены наиболее точные из них на взгляд авторов. Раскрыта сущность, фрормирование, фрунционирование и воспроизводство предпринимательского капитала. Исследовано составляющие собственного капитала и возможности оценки влияния фринансовой структуры капитала на рентабельность предприятия. Предложено сгруппированную структуру собственного капитала. Раскрыто значение учетной информации о собственном капитале предприятия для внутренних и внешних пользователей. Рассмотрены источники формирования собственного капитала на предприятии. Раскрыты особенности формирования отдельных составляющих собственного капитала. Исследована природа собственного капитала через функции, которые он выполняет на предприятии. Обобщены теоретические основы формирования собственных финансовых ресурсов предприятия, обеспечивающих его будущее развитие. Выявлены проблемы формирования собственного капитала на предприятии и даны предложения по их усовершенствованию.

Под понятием «капитал» чаще всего подразумевается понятие «собственность». Когда создается предприятие, стартовый капитал воплощается именно в активах, которые инвестируют учредители (участники), и является стоимостью имущества, принадлежащего предприятию.

Составляющими имущества предприятия являются материальные, нематериальные и финансовые ресурсы, которые являются носителями прав собственности отдельных субъектов.

Актуальность темы обусловлена тем, что собственный капитал имеет определяющее место в создании и функционировании предприятия и пользуется статусом «гаранту» организации предпринимательства.

Собственный капитал - это основа и фундамент стабильного развития предприятия. В международных стандартах бухгалтерского учета указано следующее определение собственного капитала: «Собственный капитал - это остаточная доля в активах предприятия после вычета всех его обязательств». Иными словами, собственный капитал можно трактовать как чистый капитал или чистые активы субъекта хозяйственной деятельности и является основным источником финансирования. 
Размер собственного капитала - это своего рода индикатор для инвесторов, выбирающих предприятие для осуществления своих капиталовложений.

Ключевые слова: капитал, собственный капитал, активы, обязательства понятие собственного капитал, структура собственного капитала.

\author{
Yevtushevska 0 . \\ Ph.D., Associate Professor \\ Department of Accounting and Auditing \\ E-mail: olga163alex@gmail.com \\ ORCID ID: 0000-0003-4869-5123 \\ Chernov K. \\ Undergraduate \\ Department of Accounting and Auditing \\ Odesa National Academy of Food Technologies \\ Kanatna str., 112, Odesa, Ukraine, 65039 \\ E-mail: konstantin.khilko@gmail.com \\ ORCID ID: 0000-0002-0814-0011
}

\title{
THEORETICAL ASPECTS OF ENTERPRISE EQUITY: ESSENCE AND STRUCTURE
}

The article examines the definitions of the concept of "equity capital" from the point of view of various scientists. The most common interpretations of the concept of "equity capital" have been analyzed and the most accurate of them in the opinion of the authors have been identified. The essence, formation, functioning and reproduction of entrepreneurial capital have been revealed. The components of equity capital and the possibility of assessing the influence of the financial structure of capital on the profitability of an enterprise have been investigated. A grouped equity structure has been proposed. The value of accounting information on the equity capital of an enterprise for internal and external users has been revealed. The sources of formation of equity capital at the enterprise have been considered. The features of the formation of individual components of equity capital have been revealed. The nature of equity capital has been investigated through the functions that it performs at the enterprise. The theoretical foundations of the formation of an enterprise's own financial resources that ensure its future development have been generalized. The problems of the formation of equity capital at the enterprise have been revealed and proposals for their improvement have been given.

The concept of "capital" most often means the concept of "property". When an enterprise is created, the start-up capital is embodied exactly in the assets that the founders (participants) invest, and is the value of the property owned by the enterprise.

The components of the property of the enterprise are tangible, intangible and financial resources, which are the bearers of the property rights of individual entities.

The relevance of the topic is due to the fact that equity capital has a decisive place in the creation and functioning of an enterprise and enjoys the status of a "guarantor" of an enterprise organization.

Equity capital is the basis and foundation for the stable development of the enterprise. The following definition of equity capital is specified in international accounting standards: "Equity capital is the residual share in the assets of an enterprise after deducting all its liabilities". In other words, equity capital can be interpreted as the net capital or net assets of a business entity and is the main source of financing. The amount of equity capital is a kind of indicator for investors who choose a company to make their investments.

Keywords: capital, equity, assets, liabilities, the concept of equity, the structure of equity.

\section{References}

1. Hospodarskyi kodeks Ukrainy № 436-IV vid 16.01.2003 r.: za stanom na 16.08.2020 r. (2020). Retrieved June 20, 2020, from https://zakon.rada.gov.ua/laws/show/436-15\#Text.

2. Zahalni vymohy do finansovoi zvitnosti: Natsionalne polozhennia (standart) bukhhalterskoho obliku №1: zatv. nakazom Minfinu vid 07.02.2013 r. № 73 za stanom na 31.05.2019 r. (2019). Retrieved July 7, 2020, from https://zakon.rada.gov.ua/laws/show/z0336-13/page\#Text

3. Blank, I. A. (2004). Finansovyi menedzhment (2nd ed., pererob. i dop.). Kyiv: Elga, Nika-Tsentr.

4. Butynets, F. F. (2009). Bukhhalterskyi finansovyi oblik (8th ed., dop. i pererob.). Zhytomyr: PP «Ruta». 
5. Varycheva, R. V. (2011). Vlasnyi kapital: funktsionalnyi pidkhid do traktuvannia sutnosti, napriamy klasyfikatsii u vitchyznianii ta zarubizhnii praktytsi. Visnyk ZhDTU, (2 (52)), 37-42.

6. Vivchar, O., \& Savaryn, V. (2009). Vlasnyi kapital yak finansove dzherelo funktsionuvannia pidpryiemstva. Naukovyi visnyk NLTU Ukrainy, (19.5), 146-150.

7. Horbatenko, A. A. (2010). Osoblyvosti formuvannia vlasnykh finansovykh resursiv pidpryiemstv v Ukraini. Ekonomichnyi visnyk Pereiaslav-Khmelnytskoho DPU imeni Hryhoriia Skovorody, (15/1), 195-201.

8. Bazylevych, V. D. (2008). Ekonomichna teoriia: politekonomiia (7th. ed.). Kyiv: Znannia-Pres.

9. Zahorodnii, A. H., \& Partyn, H. O. (2003). Bukhhalterskyi oblik: osnovy teorii ta praktyky (2nd ed., pererob. i dop.). Kyiv: «Znannia».

10. Ishchenko, Ya. P., \& Halaida, L. V. (2015). Teoretychni osnovy formuvannia vlasnoho kapitalu pidpryiemstva. Naukovyi visnyk Khersonskoho derzhavnoho universytetu, (15), Ch. 1, 146-148.

11. Katan, L. I. (2014). Finansovi resursy pidpryiemstva ta osoblyvosti yikh formuvannia. Visnyk Dnipropetrovskoho derzhavnoho ahrarno-ekonomichnoho universytetu, (6), 38-44.

12. Kireitsev, H. H. (2004). Finansovyi menedzhment (3rd. ed., pererob. i dop.). Kireitsev, H. H. (Ed.). Kyiv: TsNL.

13. Nuzhna, O. (2012). Vlasnyi kapital silskohospodarskykh pidpryiemstv: traktuvannia, klasyfikatsiia, struktura. Zbirnyk naukovykh prats Lutskoho natsionalnoho tekhnichnoho universytetu, (9(33)), Ch. 2, 498-507.

14. Sopko, V. V. (2007). Vlasnyi kapital aktsionernykh tovarystv: osoblyvosti vyznachennia ta obliku. Naukovyi visnyk Natsionalnoho lisotekhnichnoho universytetu Ukrainy, (17.6.), 246-253.

15. Tereshchenko, O. O. (2003). Finansova diialnist sub’iektiv hospodariuvannia. Kyiv: KNEU.

16. Tkachenko, N. M. (2008). Bukhhalterskyi finansovyi oblik, opodatkuvannia i zvitnist (3rd. ed., pererob. i dop.). Kyiv: Alerta.

Received 15 July 2020

Approved 29 July 2020

Available in Internet 15.10.2020

Цитування згідно ДСТУ 8302:2015

Євтушевська О.О., Чернов К.І. Теоретичні аспекти власного капіталу підприємства: сутність та структура // Економіка харчової промисловості. 2020. Т.12, вип. 3. С. 17-24. doi: 10.15673/fie.v12i3.1812

Cite as APA style citation

Yevtushevska, O., \& Chernov, K. (2020). Theoretical aspects of enterprise equity: essence and structure. Food Industry Economics, 12(3), 17-24. doi: 10.15673/fie.v12i3.1812 